\begin{tabular}{|l|l|l|l|l|}
\hline Cuadernos de Investigación Geográfica & 2001 & $\mathbf{N}^{\circ} 27$ & pp. 17-26 & ISSN 0211-6820 \\
\hline
\end{tabular}

(C) Universidad de La Rioja

\title{
SOIL MOISTURE IN OAK-WOOD AND PINE-WOOD OF THE MONCAYO (IBERIAN RANGE, SPAIN)
}

\author{
TERESAECHEVERRÍA \\ PALOMAIBARRA \\ JUAN MARTÍNEZ
}

Department of Geography and Territory Planning, University of Zaragoza,

50.009 - Zaragoza, Spain

ABSTRACT: Water behaviour in forest soils, an oak-wood (Quercus pyrenaica) and a pine-wood (Pinus sylvestris) located on the northern side of the Moncayo Massif (Sistema Ibérico, Zaragoza, Spain) is analysed in this study. The results demonstrate the different behaviour of water in the soils of the two forests subject to study. Soil moisture values correspond to the different depths (dead leaves, 0-5, 5-10 and 10-15 cm) and at different times during the year, and are related to climatic parameters such as rain fall and temperature, linked phenologically to the presence of canopy and soil cover, pointing out the texture and quantity of organic matter in each of the defined depths.

A clear seasonal behaviour of soil moisture in relation to climatic and phenological factors is observed in both forests. Soil moisture is always higher in the pine-wood in the upper subhorizons (0-5 and 5-10 cm), and in the oak-wood in the lower ones $(10-15 \mathrm{~cm})$.

RESUMEN: Se ha estudiado el comportamiento hidrológico de un rebollar (Quercus pyrenaica) y de un pinar (Pinus sylvestris) en la cara norte del macizo del Moncayo (Sistema Ibérico). Los resultados demues tran el diferente funcionamiento del agua en el suelo de los dos bosques estudiados. Los valores de humedad del suelo corresponden a diferentes profundidades (hojarasca, 0-5, 5-10 and 10-15 cm) y a diferentes momen tos del año. Se han relacionado con parámetros climáticos como precipi tación y temperatura, así como la textura y cantidad de materia orgánica a cada profundidad.

Un claro comportamiento estacional se ha observado en ambos bos ques en relación con factores climáticos y fenológicos. Las diferencias en humedad del suelo son siempre a favor del pinar en los subhorizontes superiores, y a favor del pinar en el inferior.

Key-words: Soil moisture, Forest water balance, Quercus pyrenaica, Pinus sylvestris, Moncayo, Spain.

Palabras clave: Humedad del suelo, Balance hídrico forestal, Quercus pyrenaica, Pinus sylvestris, Moncayo, España. 


\section{Introduction and study area}

The behaviour of water in the forest and in the soil are interesting subjects to understand the environmental dynamics of forest ecosystem. Research concerning this matter is frequent in the Mediterranean environment, where a long water stress is recorded (Calamini, et al., 1982; Bellot, 1988; Diz et al., 1991; Belmonte \& Romero, 1994; Giacomin \& Trucchi, 1992).

The amount of water that reaches the soil in a forest depends on the effect that some climatic factors, such as wind, insolation and other bio-geographic factors that are linked to the forest structure itself, exert on the rainfall. These factors are also related to its density, stratification and to the physiognomic characteristics of the dominant species. Both factor groups control some mechanisms such as interception, stemflow and rain throughfall through the leaf cover. Furthermore, when water reaches the soil surface its infiltration is conditioned by the soil physico-chemical characteristics, fundamentally by the presence of leaves duff, the texture, structure and amount of organic matter.

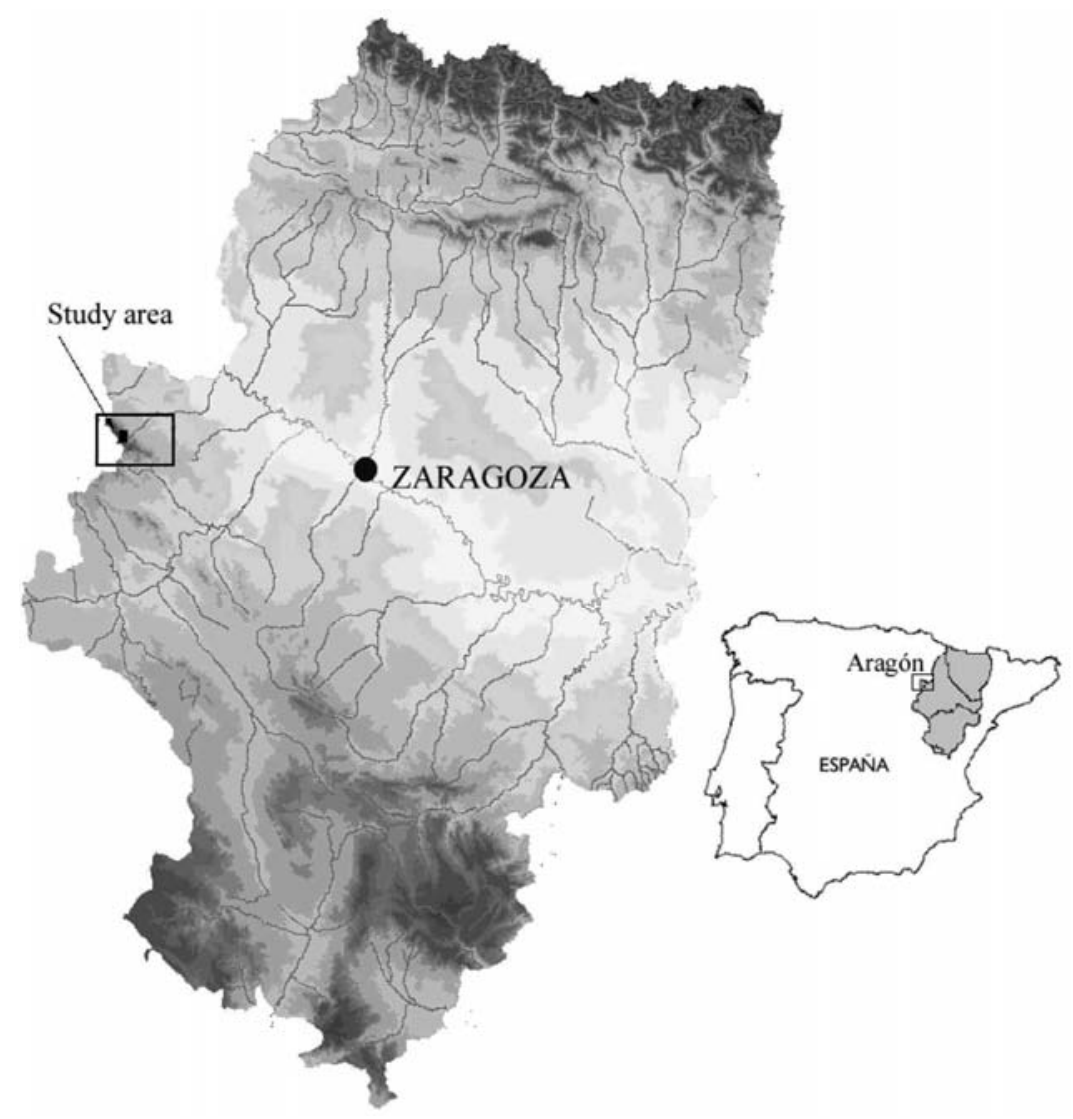

Figure 1. Site of the study area 
Nevertheless the study of the behaviour, quantity and temporal evolution of water in the soil is a subject which deserves more attention as regards to the water recipient of the «forest system». This is why we try to deepen into the interconnections between climate, soil and vegetation, which is the objective of the present study.

The study area is the northern side of the Massif of Moncayo (Figure 1). There, a first approximation of the forest water balance has already been carried out (Echeverría et al., in press) by means of a hypothetical model, in which it is acknowledged that most of the water reaching the soil infiltrates, and so considering that the superficial runoff is insignificant. In this model, infiltration and percolation are related to the rain throughfall in the forest, to the stemflow and to the evaporation-transpiration of the soil itself. In this context, this work aims to deepen into the behaviour of water in the soil detecting interconnections between the soil itself, the vegetation and the climatic parameters.

In the study area the woodland is still in a good state of conservation. The altitudinal gradient of this side of the massif is very steep (from \pm 700 to $2.315 \mathrm{~m}$ ), and this fact explains the important thermal and pluviometric variations that result in the existence of different bio-climatic layers with contrasting plant communities (Navarro, 1989, Ibarra et al. 1995). So, from the base to the summit, the following plant communities are found: holm-oak woods (Junipero oxycedri-Quercetum rotundifoliae), typical Mediterranean vegetation of sclerophyllous and perennial leaves, located between 700 and 900m.; the humid oak-woods (Festuco heterophyllae-Quercetum pyrenaicae) and some oak-woods (Linario triormithophorae-Quercetum petraa), forests with marcescent leaves which represent the transition between the Mediterranean and the Euro-Siberian vegetation growing at altitudes between 1000 and $1200 \mathrm{~m}$; the beech-woods (Ilici aquifolii-Fagetum syl vaticae) between 1200 and $1500 \mathrm{~m}$, deciduous forests characteristic from the EuroSiberian regions, which were substituted in wide areas by reforestations from the turn of the century by Pinus sylvestris; which are still in many cases in an excellent state of conservation (and grow at altitudes up to approximately $1700 \mathrm{~m}$ ); trailing juniper-wood (Vaccinio myrtilli-Junipereto nanae) that grow in the summits above the limits of the Crioro-Mediterranean forest and grazing land (Antennario dioicae-Festuceto aragonen sis). Among these communities, two of the woods with very defined and contrasting characteristics have been selected for the installation of experimental: the oak-wood and the pinewood. (Figure 1).

The north-western side of the massif of Moncayo, where these stations are located, is made up of an anticlinal quartzite and Paleozoic slate nucleus covered by sandstones, siliceous conglomerates and Triassic slates. But this substrate is in its greatest part recovered by strong soil creep deposits which include spalls, boulders and rocks, among the hard materials, and siliceous with a clayey-sandy matrix (Pellicer, 1985). The pinewood soil as well as the oak-wood soil has developed from these allochthonous sediments, but the greatest amount of clayey matrix is situated at lower levels on the slope, where the oak-wood patch is found, and which has a more gentle slope and links with the foothills. 


\section{Material and method}

The work presented is part of a project on the water balance analysis in different forests. It is based on an experimental study that starts with the collection of environmental data after the installation of the equipment for measurement in diverse experimental areas of $625 \mathrm{~m}^{2}$ (Echeverría et al., in press). The data, which was collected between October, 1993 and October,1996, is now used: soil moisture, rainfall and maximum temperatures, all of these are taken from the interior of the stated forests.

The soil moisture data was collected fortnightly. Four samples were taken from each plot at different depth levels. The fresh and loose forest duff of the year, one section from 0 to $5 \mathrm{~cm}$, another from 5 to $10 \mathrm{~cm}$ and the last one from 10 to $15 \mathrm{~cm}$. These samples were kept in hermetic bags and on the following day, their moisture content was calculated in the laboratory by means of the gravimetric method (drying for 36 hours at $105^{\circ} \mathrm{C}$ ). The sections of the soils were described and classified (F.A.O. 1998) and the subhorizons or $5 \mathrm{~cm}$ sections studied in the moisture variations analysis were characterised from the mixture of several fortnightly samples (organic and mineral fraction, texture, organic matter by calcination, $\mathrm{pH}$ ).

Rainfall, in the interior of the forest, is divided into processes such as the rain throughfall through the vegetation cover, which is measured by pluvioscopes ( 3 pluvioscopes in each forest) and the stemflow measured by a collar system encircling the trunk of the tree and linked to a drainpipe ( 6 drainpipes in each forest). These values total the rainfall in the wood and have been taken fortnightly.

\section{Results and comments}

The pine-wood patch is located on the high part of the regularised slope, at 1,600 m., where a high gradient (greater than $40 \%$ ) and high levels of stoniness are found. An annual average of $798.8 \mathrm{~mm}$ of rainfall was collected, the soil is excessively drained, more than $150 \mathrm{~cm}$ thick and has the following horizons: O - A - E - Bs - BC. Processes of important podsolisation linked to low temperatures, high humidity and acidic environment due to vegetation as well as to substratum have been described (Fidalgo \& Ibarra, 2000), although some authors for nearby areas have confirmed that they fulfil the requested conditions for an spodic horizon (Carceller, 1995) -whereas other authors have not confirmed it (Arrechea and Tejera, 1990). It would be classified as Haplic spodosol or Humic umbrisol in evolution towards a podsol.

The average thickness of the organic horizon is $8 \mathrm{~cm}$ whereas the A-horizon is $35 \mathrm{~cm}$ thick. The colour when dried is 7,5 YR 4/2, and has a marked texture, crumbled structure, moderate, medium; very friable; frequent small and continuous pores; frequent rock fragments (25-30\%); non calcareous; $\mathrm{pH} 3,5$; very abundant roots of all sizes; net limit, flat. In the pinewood plot the fresh forest duff that was collected is mainly made up of acicular leaves, which is easily identified, small pine branches, heather or pieces of pine bark. The $0-5 \mathrm{~cm}$ subhorizon belongs to the organic horizon ( $86 \%$ organic material by 
calcination), which is made of a spongy and soft mass in a blackish-brown colour, an acicular layer and small branches that can hardly be identified. The $5-10 \mathrm{~cm}$ subhorizon has very little fresh organic matter and the mineral fraction is dominant here (21\% organic material by calcination), whereas in the $10-15 \mathrm{~cm}$ subhorizon there is no presence of forest duff (9\% organic material by calcination). The texture analysis of the mixture of thicknesses from 0 to $15 \mathrm{~cm}$ (44 \% of sand, 31\% of slime and $17 \%$ of clay) confirms that the soil surface is sandy (much more than the oak-wood soil) and this will influence its ability to percolate with ease.

In the oak-wood patch, located on the low part of the north-western slope of the massif, an annual average of $513.3 \mathrm{~mm}$ of rainfall is collected. The gradient is much smoother (around $10 \%$ ), it is less stony (3-15\%) and does not show evident erosive processes under the dense foliage cover of the oak-wood. It reaches a development greater than $2 \mathrm{~m}$ and its section in the sector of the survey is $\mathrm{O}-\mathrm{A}-\mathrm{AB}-\mathrm{Bw}-\mathrm{BC}$. It is classified as Dystric Cambisol and in this case, the dominant processes are those of darkening and in situ alteration in the deeper horizons, although some incipient eluviation processes can be observed in the AB-transition horizon as well as iron mobilisations in the Bw horizon. This difference in the dominant soil processes can be explained by milder climatic conditions, lesser amount of rainfall and foliage cover. Under these conditions, the organic horizon has an average thickness of $3 \mathrm{~cm}$, a much lower value than in the pinewood area. The A-horizon is some $25 \mathrm{~cm}$ thick, has a dry colour 10YR 6/3, marked clayey structure, moderate primary and medium granulated structureand sub-angular secondary fine structure; $\mathrm{pH}$ is 4,8 ; there are abundant medium and thick roots; net limit.

In the case of the oak-wood, the forest duff is obviously made up of abundant plainleaves, some twigs and acorns. In contrast to the pinewood, the $0-5 \mathrm{~cm}$ depth level is made up of $20 \%$ of organic horizon and $80 \%$ of the A-mineral horizon (26\% organic material by calcination). Only mineral horizon is collected below $5 \mathrm{~cm}$ presenting $13 \%$ organic material by calcination the $5-10 \mathrm{~cm}$ subhorizon (well below the pinewood), and $9 \%$ between $10-15 \mathrm{~cm}$ (value similar to the pinewood). The texture analysis of the mixture of thicknesses from 0 to $15 \mathrm{~cm}$ ( $28 \%$ of sand, $39 \%$ of silt and $29 \%$ of clay) shows that this soil is much more clayey than the pinewood soil, and this has a great influence in the retention capacity of the water filtered through the soils (higher in the oak-wood).

In figure 2 (and Table 1) the fortnightly values of soil moisture throughout the year, corresponding to different depths in the forests selected are represented.

The soil moisture shows a marked seasonal trend, in direct relation to precipitation, although the amplitude of the oscillations between the periods of humidity contrasted reduces with depth.

Humidity values oscillate between a winter maximum, based on high precipitations and low temperatures, and a summer minimum, linked to low precipitations and high temperatures. Spring represents the second maximum, which prolongs winter climatic conditions, especially in the pinewood area. 
Teresa Echevarría, Paloma Ibarra \& Juan Martínez
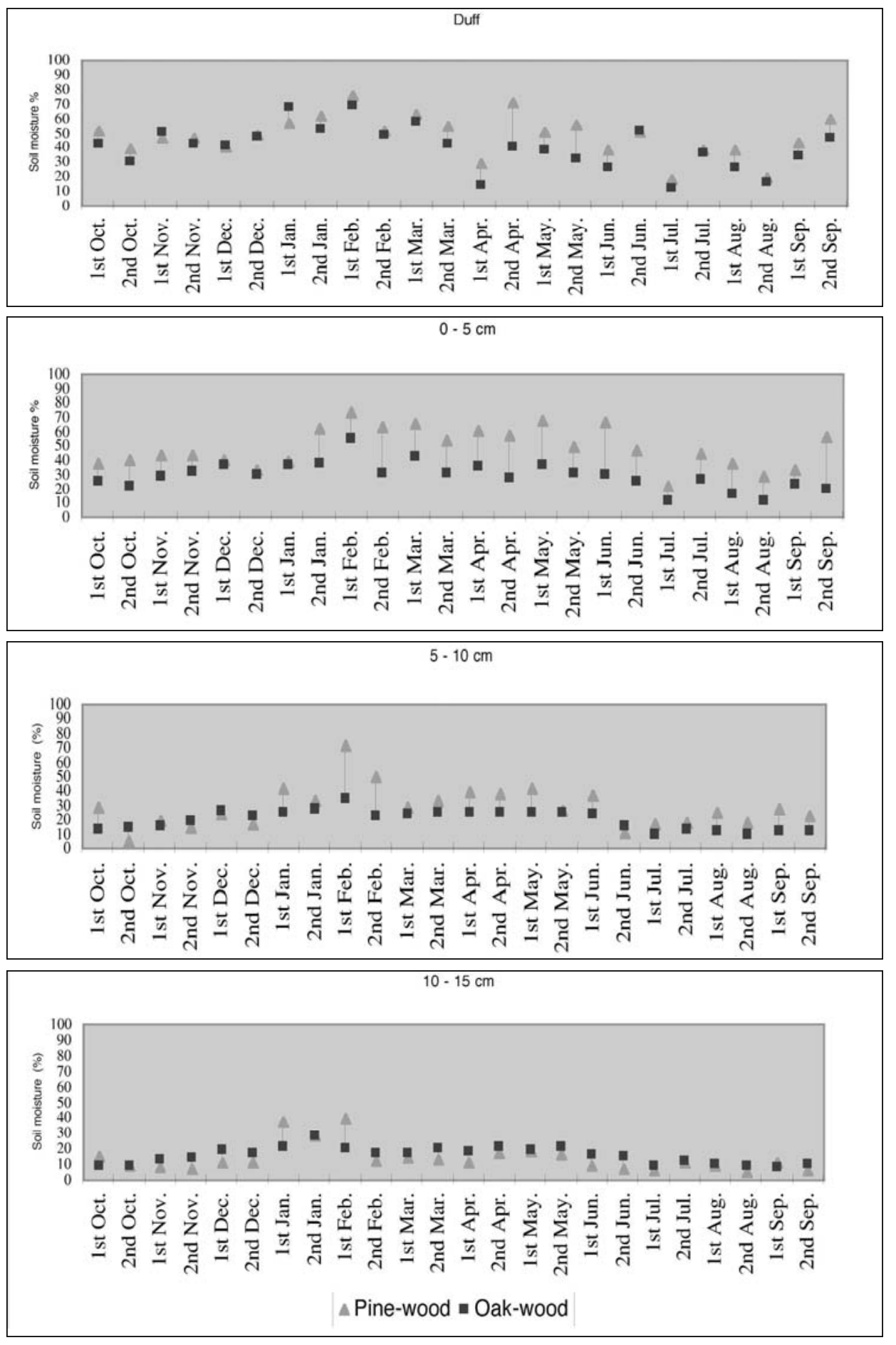

Figure 2. Fortnightly soil moisture evolution. 
Table 1. Seasonal averages records from october 1993 to october 1996

\begin{tabular}{|c|c|c|c|c|c|c|}
\hline \multirow[t]{2}{*}{ Pine-wood } & \multicolumn{4}{|c|}{$\%$ Soil moisture } & \multicolumn{2}{|c|}{$\max . T^{a}$ rain fall } \\
\hline & Duff & $0-5 \mathrm{~cm}$ & $5-10 \mathrm{~cm}$ & $-15 \mathrm{cn}$ & & \\
\hline Autumn & 45,47 & 39,71 & 17,85 & 10,33 & 11,38 & 238,59 \\
\hline Winter & 60,35 & 59,48 & 43,27 & 24,17 & 9,17 & 255,12 \\
\hline Spring & 49,13 & 58,62 & 32,00 & 13,22 & 18,10 & 161,55 \\
\hline Summer & 36,21 & 37,28 & 21,27 & 8,11 & 23,72 & 143,52 \\
\hline Year & 47,79 & 48,77 & 28,60 & 13,96 & 15,59 & 798,8 \\
\hline
\end{tabular}

Oak-wood

\begin{tabular}{|cccc|c|c|}
\multicolumn{1}{c}{ \% Soil moisture } & \multicolumn{3}{c}{ max. T} & rain fall \\
\hline Duff & $0-5 \mathrm{~cm}$ & $5-10 \mathrm{~cm} 10-15 \mathrm{~cm}$ & \\
\cline { 1 - 4 } 42,28 & 29,20 & 18,35 & 13,54 & 16,42 & 165,44 \\
56,30 & 39,16 & 26,61 & 20,86 & 15,50 & 157,74 \\
33,85 & 31,08 & 23,19 & 18,47 & 24,53 & 101,48 \\
28,71 & 17,86 & 11,05 & 9,45 & 29,92 & 90,70 \\
40,29 & 29,32 & 19,80 & 15,58 & 21,59 & 515,3 \\
\hline
\end{tabular}

Soil moisture values in pinewood soils are higher than those of oak-wood soils throughout the year. These differences reach a maximum in spring, when the oak-wood foliage cover is dense and, therefore, the interception of rain affects the groundwater. In Autumn the differences between soil moisture in both forests are minimal, given the Autumn pluviometric maximum of the oak-wood area, whose ground in this season is less protected by the vegetation, reducing the humidity differences with respect to the pinewood.

Analysis of the selected subhorizons in each of the grounds permits the addition to the climatic factor, responsible for the seasonal tendency, of other environmental factors that explain the behaviour of the groundwater.

The forest duff presents the highest values of soil moisture, as much in the pinewood area (36.21-60.35\%) as in the oak-wood area (28,71-56.30\%). The values of both forests are softened during the year. The oak-wood forest duff of integrated plain-leaves absorbs a substantial quantity of water, while the acicular leaves of the pinewood forest duff present a reduced retention capacity, acting as an effective filter towards inferior subhorizons. The seasonal behaviour of humidity is marked at this level in which the humidity entrances and exits in relation to climatic factors are demonstrated with clarity.

The $0-5 \mathrm{~cm}$ subhorizon shows the most marked differences between the soil moisture values of both forests, highlighting the contrasts in the spring, 58.62\% in the pinewood area and $31.08 \%$ in the oak-wood area, a stage in which the water reaching the ground of the oak-wood area is protected against evaporation by the dense foliage cover.

These differences in the $0-5 \mathrm{~cm}$ subhorizon fundamentally respond to a distinct characterisation of the organic horizon in both soils. The greater quantity of organic material and its grade of compactness in the pinewood cause an important amount of water reten- 
tion, whilst in the oak-wood area, water continues to filter deep into the soil in spite of incipient hydrophobic behaviour.
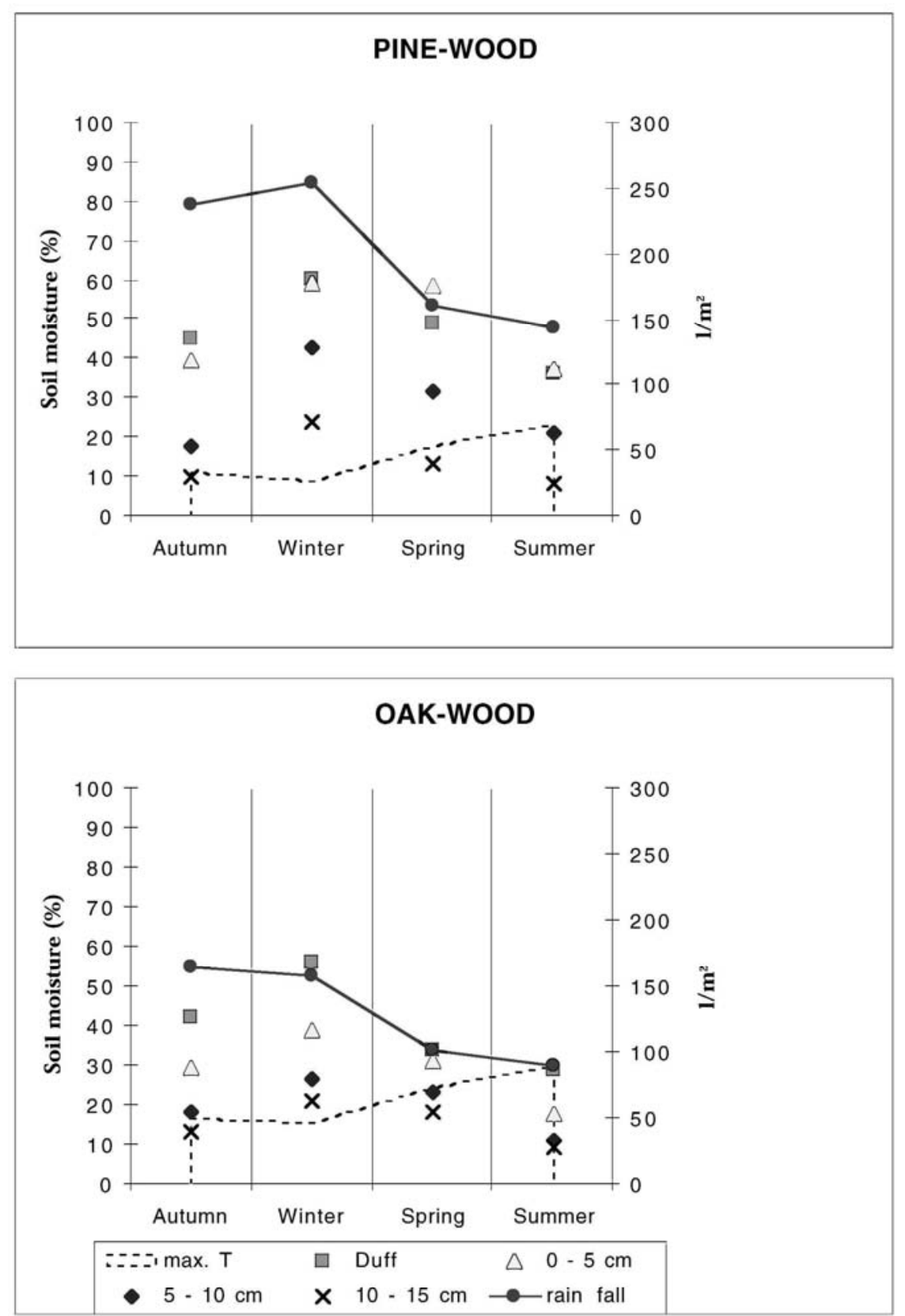

Figure 3. Seasonal soil moisture evolution, rainfall and maximum temperatures within the forest. 
However, the humidity differences observed throughout the year are softened in Autumn, a period in which the humidity values become closer, answering the phenological-climatic factor already mentioned and related to the scarce foliage cover of the oakwood area and the autumn pluviometric maximum observed in this forest; moreover, the low summer humidity retained by the oak-wood area, $17.86 \%$, against the $37.28 \%$ in the pinewood area, favours the absorption of a greater quantity of water in Autumn.

The greater humidity in the pinewood soils throughout the year and the distinct subhorizons loses importance (becoming blurred) until it reaches the inferior analysed level, $10-15 \mathrm{~cm}$, in which the humidity values are inverted throughout the year, giving higher oak-wood soil moisture figures $(15.58 \%$ average annual humidity, against $13.96 \%$ of the pinewood soil). To explain this behaviour textural factors must be considered, given that the greater quantity of clays in the oak-wood soil favours high water retention, while the sandier pinewood soil presents higher values of infiltration, increased by the topographic gradient.

Finally, and observing Figure 3 (and table 1) it must be concluded that the soil moisture factors show a clear seasonal behaviour in relation to climatic factors, although the presence of groundwater answers to other environmental factors typical for each forest, such as the topographic gradient, some soil parameters - texture and characterisation of the organic material - and, especially, the role played by the varied phenology of the oak-wood area in contrast to the more homogeneous pinewood area throughout the year.

\section{References}

Arrechea, E. \& Tejera, R. (1990). Los suelos del Moncayo. In TRAGSA. Plan de Ordenación de los Recursos Naturales de la Comarca del Moncayo. pp. 73-185.

Bellot, J. (1988). Análisis de los flujos de deposición global, trascolación, escorrentía cortical y deposición seca en el encinar mediterráneo de l'Avic (Sierra de Prades, Tarragona). Tesis Doctoral, Univ. de Alicante (Inédita).

Belmonte, F. \& Romero, M.A. (1994). Distribución de flujos de agua en el proceso de interceptación en cuatro especies vegetales mediterráneas y su relación con la cantidad de agua en el suelo. En: Arnáez, J., García Ruiz, J.M. y Gómez Villar, A. (Eds.): Geomorfología en España. III Reunión de Geomorfología, SEG, (II),201-210.

Calamini, G., Falciai, M., Giacomin, A. \& Grazi, S. (1982). Misura delle influenze di un bosco ceduo sui parametri idrologici (III rapporto). Dinamica dell' acqua nel terreno e bilancio idrologico neibacini agroforestali,337-353, Padova.

Carceller, F. (1995). Dinámica forestal y ciclo de nutrientes en los bosques de la vertiente Norte del Moncayo. Tesis doctoral. Departament de Biologia vegetal. Universitat de Barcelona. 360 pp.

Diz, J, López, J. \& Giráldez, J.V. (1991): La influencia del bosque en el aprovechamiento de los recursos hidrológicos, II Jornadas del Agua en Andalucía, 139-150. 
Echeverría, M.T., Hernández, Mª L., Ibarra, P., Marín, J.Ma , Martínez, J., Moreno, J., Pérez,Ma.L. \& Santacecilia, M.A. (in press). El estudio del ciclo del agua en un ambiente forestal del Macizo del Moncayo; metodología y primeros resultados en un pinar a $1.600 \mathrm{~m}$. Actas del I Congreso sobre la Cordillera Ibérica, Tarazona.

F.A.O. (1998). World Reference Base for Soil Resources. World Soil Resources Reports n. 84, F.A.O. Roma

Fidalgo, C. \& Ibarra, P. (2000). Secuencia de suelos en la vertiente NO. del Macizo del Moncayo. Resultados del trabajo de campo. En Homenaje a D. Jesús García Fernández. Secretaria de Publicaciones de la Universidad de Valladolid.

Giacomin, A. \& Trucchi, P. (1992). Rainfall interception in a beech coppice (Acquerino,Italy). Journal of Hidrology, 137, 141-147.

Ibarra, P., Longares, L.A. \& Sese, P. (1995). Contraste entre las comunidades vegetales del Macizo del Moncayo; factores ambientales y antrópicos. Actas de las XV Jornadas de Fitosociología, Mallorca.

Navarro, G. (1989). Datos sobre la vegetación del Moncayo. Turiaso, 9: 423-431.

Pellicer, F. (1985): Geomorfología de las Cadenas Ibéricas entre el Jalón y el Moncayo. Cuadernos de Estudios Borjanos 11-14:1-389. 